Article

\title{
Proteomic Analysis of the Responses of Candida albicans during Infection of Galleria mellonella Larvae
}

\author{
Gerard Sheehan 1 and Kevin Kavanagh * \\ Medical Mycology Laboratory, Department of Biology, Maynooth University, Maynooth, W23F2H6 Co. Kildare, \\ Ireland; Gerard.Sheehan@mu.ie \\ * Correspondence: Kevin.Kavanagh@mu.ie; Tel.: +353-1-708 3859; Fax: +353-1-708-3845
}

Received: 12 December 2018; Accepted: 9 January 2019; Published: 11 January 2019

check for updates

\begin{abstract}
This study assessed the development of disseminated candidiasis within Galleria mellonella larvae and characterized the proteomic responses of Candida albicans to larval hemolymph. Infection of larvae with an inoculum of $1 \times 10^{6}$ yeast cells reduced larval viability $24(53.33 \pm 3.33 \%), 48$ $(33.33 \pm 3.33 \%)$ and $72(6.66 \pm 3.33 \%) h$ post infection. C. albicans infection quickly disseminated from the site of inoculation and the presence of yeast and hyphal forms were found in nodules extracted from infected larvae at 6 and $24 \mathrm{~h}$. A range of proteins secreted during infection of G. mellonella by C. albicans were detected in larval hemolymph and these were enriched for biological processes such as interaction with host and pathogenesis. The candicidal activity of hemolymph after immediate incubation of yeast cells resulted in a decrease in yeast cell viability $\left(0.23 \pm 0.03 \times 10^{6}\right.$ yeast cells $/ \mathrm{mL}), p<0.05)$ as compared to control $\left(0.99 \pm 0.01 \times 10^{6}\right.$ yeast cells $\left./ \mathrm{mL}\right)$. C. albicans responded to incubation in hemolymph ex vivo by the induction of an oxidative stress response, a decrease in proteins associated with protein synthesis and an increase in glycolytic proteins. The results presented here indicate that $C$. albicans can overcome the fungicidal activity of hemolymph by altering protein synthesis and cellular respiration, and commence invasion and dissemination throughout the host.
\end{abstract}

Keywords: Candida; Galleria; infection; immunity; mini-model; in vivo screening

\section{Introduction}

Insects are now a widely used alternative to mammals for assessing the virulence of a range of medically important microbial species such as Candida albicans [1,2], Aspergillus fumigatus [3-5], Pseudomonas aeruginosa [6], or Campylobacter jejuni [7] and display many advantages over the use of mammals [8]. Larvae of Galleria mellonella possess added advantages over other insect species as they may be incubated at $37^{\circ} \mathrm{C}$, are easy to handle, possess a large volume of hemolymph with a high density of immune cells which can be used in a range of ex vivo assays using techniques already established with mammalian granulocytes [9]. Infection of larvae can be assessed by many end points including survival, extent of melanization, variations in hemocyte density and microbial load, histopathology, nodule formation and alterations in proteome [9-11].

The insect immune response shows many similarities to the mammalian innate defense system [12]. Insect hemocytes display distinct anatomical and biochemical similarities to human phagocytes. Pathways such as IMD and Toll have homologues in mammals and lead to the production of a variety of antimicrobial peptides (AMPs) which play an essential role in curtailing microbial growth. These include a range of anti-fungal peptides such as gallerimycin, a cationic inducible cysteine rich defensin like peptide with antifungal activity, galliomicin a 43 amino acid AMP which is induced by C. albicans [13-16]. Lepidopterans also produce moricins which are $\alpha$-helical peptides which are highly 
active against yeasts and filamentous fungi [17]. Furthermore, glycine-rich gloverins AMPs were significantly increased in abundance in response to infection by C. albicans and A. fumigatus [10,18]. Insect cecropins are a class of $\alpha$-helical peptides which target the fungal membrane and induce apoptosis of C. albicans and possess immunomodulatory effects on mammalian macrophages $[19,20]$.

C. albicans is a dimorphic yeast capable of causing a wide range of systemic and disseminated diseases in immunocompromised patients and is believed to cause 400,000 deaths per annum [21,22]. C. albicans possesses a variety of virulence attributes which it uses to detoxify and subvert the immune response (e.g., secreted aspartyl proteinases), invade through tissue and disseminate throughout the host [23]. G. mellonella larvae have been employed to study host fungal-pathogen interactions [18]. C. albicans infection in larvae results in alterations in immune cell function and type, changes in hemolymph proteins (antimicrobial peptides, opsonin, proteins indicative of invasion) in an attempt to control the increasing fungal burden which shows pathologies similar to disseminated renal candidiasis in mice [18].

The aim of this study was to characterize the infection processes and dissemination of C. albicans in G. mellonella larvae and to assess the responses of $C$. albicans as it interacts with the larval immune response.

\section{Materials and Methods}

\subsection{Larval Culture and Inoculation}

Sixth instar larvae of the greater waxmoth G. mellonella (Livefoods Direct Ltd, Sheffield, England), were stored in the dark at $15{ }^{\circ} \mathrm{C}$ to prevent pupation. Larvae weighing $0.22 \pm 0.03 \mathrm{~g}$ were selected and used within two weeks of receipt. Larvae were used according to standard procedures [18]. Ten healthy larvae per treatment and controls $(n=3)$ were placed in sterile petri dishes lined with Whatman filter paper and containing some wood shavings. Larvae were acclimatized to $30^{\circ} \mathrm{C}$ for $1 \mathrm{~h}$ prior to all experiments and incubated at $30^{\circ} \mathrm{C}$ for all studies. All experiments were performed independently on three separate occasions.

\subsection{Yeast Strain}

Candida albicans MEN (a kind gift from Dr. D. Kerridge, Cambridge, UK) was cultured in YEPD broth $(2 \%(w / v)$ glucose, $2 \%(w / v)$ bactopeptone (Difco Laboratories, Detroit, MI, USA), $1 \%(w / v)$ yeast extract (Oxoid Ltd., Basingstoke, UK)) at $30^{\circ} \mathrm{C}$ and $200 \mathrm{rpm}$ in an orbital shaker overnight. Stocks were maintained on YEPD agar plates (as above but supplemented with $2 \%(w / v)$ agar).

\subsection{Effect of Candida albicans Infection on G. mellonella Larvae}

Larvae were inoculated with C. albicans $\left(1 \times 10^{4}\right.$ to $1 \times 10^{7} / 20 \mu \mathrm{L}$ PBS solution) through the last left pro-leg and incubated at $30^{\circ} \mathrm{C}$. Survival of larvae was recorded at 24,48 , and $72 \mathrm{~h}$.

\subsection{Cryo-Imaging of C. albicans Infection in G. mellonella}

G. mellonella were inoculated with $5 \times 10^{5}$ C. albicans cells for 0,6 , and $24 \mathrm{~h}$ at $30{ }^{\circ} \mathrm{C}$. Larval movement was inhibited by placement on ice. Larvae were embedded in Bioinvision Embedding Compound and flash-frozen in liquid nitrogen and mounted on a stage for sectioning. Sectioning and imaging was carried out every $10 \mu \mathrm{m}$ using a CryovizTM (Bioinvision Inc., Cleveland, OH, USA) cryo-imaging system.

\subsection{Confocal Imaging of Fungal Nodules}

G. mellonella larvae infected with $C$. albicans $\left(5 \times 10^{5} / 20 \mu \mathrm{L}\right)$ for 6 and $24 \mathrm{~h}$ at $30^{\circ} \mathrm{C}$ were dissected in PBS and nodules dissected apart with fine needles, transferred to a glass slide and stained with Calcofluor white (Sigma, Gillingham, UK) for $30 \mathrm{~min}$ at $16^{\circ} \mathrm{C}$. The cells were washed twice with PBS and a cover slide was placed on top. Cells were viewed with an Olympus Fluoview 1000 confocal microscope. 


\subsection{Identification of C. albicans Proteins Secreted during Infection of G. mellonella Larvae}

Ten larvae $(n=4)$ were infected with C. albicans $\left(5 \times 10^{5} / 20 \mu \mathrm{L}\right)$ for $24 \mathrm{~h}$ at $30^{\circ} \mathrm{C}$. Hemolymph was collected, hemocytes removed by centrifugation $10,000 \times g$ for $10 \mathrm{~min}$ and hemolymph diluted in PBS, quantified using Biorad Bradford protein quantification assay and acetone precipitated overnight (75 $\mu \mathrm{g})$. Proteins were subjected to label free quantitative LC-MS/MS.

\subsection{Ex Vivo Hemolymph Fungicidal Activity Assay}

Hemolymph $(1 \mathrm{~mL})$ was extracted from G. mellonella larvae, hemocytes were removed by centrifugation $(10,000 \times g$ for $10 \mathrm{~min})$ and diluted with PBS. C. albicans cells $\left(1 \times 10^{6} / \mathrm{mL}\right)$ were suspended in $1 \mathrm{~mL}$ of each dilution of hemolymph $\left(100,50,25 \%\right.$; maintained at $\left.30{ }^{\circ} \mathrm{C}\right)$ and PBS and aliquots taken at $0,2,4,6$, and $24 \mathrm{~h}$ and plated on YEPD agar plates supplemented with erythromycin $(0.1 \mathrm{mg} / \mathrm{mL})$. Effect on yeast cell viability was determined by enumerating resulting colonies after incubation.

\subsection{Protein Isolation and Purification from C. albicans Exposed to Larval Hemolymph}

C. albicans cells $\left(2.5 \times 10^{7} / \mathrm{mL}\right)$ were incubated in PBS or G. mellonella hemolymph $(100 \% ; 1 \mathrm{~mL})$ for $6 \mathrm{~h}$ in Eppendorf tubes $(n=4)$ shaking at $200 \mathrm{rpm}$. Cells were centrifuged at $8000 \times g$ for $10 \mathrm{~min}$, washed 3 times with PBS and resuspended in lysis buffer $(6 \mathrm{M}$ urea, $2 \mathrm{M}$ thiourea, $0.1 \mathrm{M}$ Tris- $\mathrm{HCl}$ and supplemented with protease inhibitor cocktail and $\mathrm{pH}$ adjusted to 8 ), subjected to sonication cycles $(30 \%, 10 \mathrm{~s}, 3$ cycles) and clarified by centrifugation $(10,000 \times g$ for $10 \mathrm{~min})$. C. albicans whole cell protein was acetone precipitated $(75 \mu \mathrm{g})$ overnight by the addition of 3 times total volume of ice cold acetone. Proteins were subjected to label free quantitative LC-MS/MS.

\subsection{Label Free Quantitative Proteomics Workflow}

Protein samples were analyzed by label free mass spectrometer by standard protein purification procedures as described [10]. Peptide mix ( $1 \mu \mathrm{L}$ of $0.75 \mu \mathrm{g} / \mu \mathrm{L}$ sample) was eluted onto a Q-Exactive (ThermoFisher Scientific, Waltham, MA, USA) high resolution accurate mass spectrometer connected to a Dionex Ultimate 3000 (RSLCnano) chromatography system. Peptides were separated by an increasing acetonitrile gradient on a Biobasic C18 Picofrit ${ }^{\mathrm{TM}}$ column (ThermoFisher Scientific, Waltham, MA, USA) using a $195 \mathrm{~min}$ reverse phase gradient at a flow rate of $250 \mathrm{~nL} / \mathrm{min}$. A high resolution MS scan (300-2000 Dalton) was performed using the Orbitrap to select the 15 most intense ions prior to MS/MS.

Protein identification from the MS/MS data was performed using the Andromeda search engine in MaxQuant (version 1.2.2.5; http:/ / maxquant.org/) to correlate the data against the proteome of C. albicans (for response of C. albicans to hemolymph) obtained from uniport and the EST contigs of G. mellonella obtained in house.

Results processing, statistical analyses and graphics generation were conducted using Perseus v. 1.5.5.3 as described [10]. Proteins that had non-existent values (indicative of absence or very low abundance in a sample) were also used in statistical analysis of the total differentially expressed group following imputation of the zero values using a number close to the lowest value of the range of proteins plus or minus the standard deviation. After data imputation these proteins were included in subsequent statistical analysis. Identified proteins were grouped into functional categories based on the GO (Gene Ontology) annotations, using the FungiFun application [24]. The Search Tool for the Retrieval of INteracting Genes/Proteins (STRING) [25] v10.5 (http:/ / string-db.org/) was used to map known and predicted protein:protein interactions. UniProt gene lists (extracted from Perseus) were inputted and analyzed in STRING using the medium confidence (0.5) setting to produce interactive protein networks for proteins increased and decreased in abundance. 


\subsection{Statistical Analysis}

All experiments were performed on three independent occasions and results are expressed as the mean \pm S.E. analysis of changes in viability of C. albicans in larval hemolymph was performed by One-way ANOVA. All statistical analysis listed performed using GraphPad Prism v6. Differences were considered significant at $p<0.05$.

\subsection{Data Availability}

The MS proteomics data and MaxQuant search output files have been deposited to the ProteomeXchange Consortium [26] via the PRIDE partner repository with the dataset identifier PXD011997 for response of C. albicans to hemolymph.

\section{Results}

\subsection{The Effect of C. albicans Infection on G. mellonella Larvae}

Infection of G. mellonella larvae with $C$. albicans at $1 \times 10^{4} / 20 \mu \mathrm{L}$ and $1 \times 10^{5} / 20 \mu \mathrm{L}$ did not significantly alter larval viability $72 \mathrm{~h}$ post infection. However, an inoculum of $1 \times 10^{6} / 20 \mu \mathrm{L}$ significantly reduced larval viability at $24(53.33 \pm 3.33 \%), 48(33.33 \pm 3.33 \%)$ and $72(6.66 \pm 3.33 \%) \mathrm{h}$. Infection of larvae with C. albicans cells at a density of $1 \times 10^{7} / 20 \mu \mathrm{L}$ resulted in no larval survival $24 \mathrm{~h}$ post infection (Figure 1).

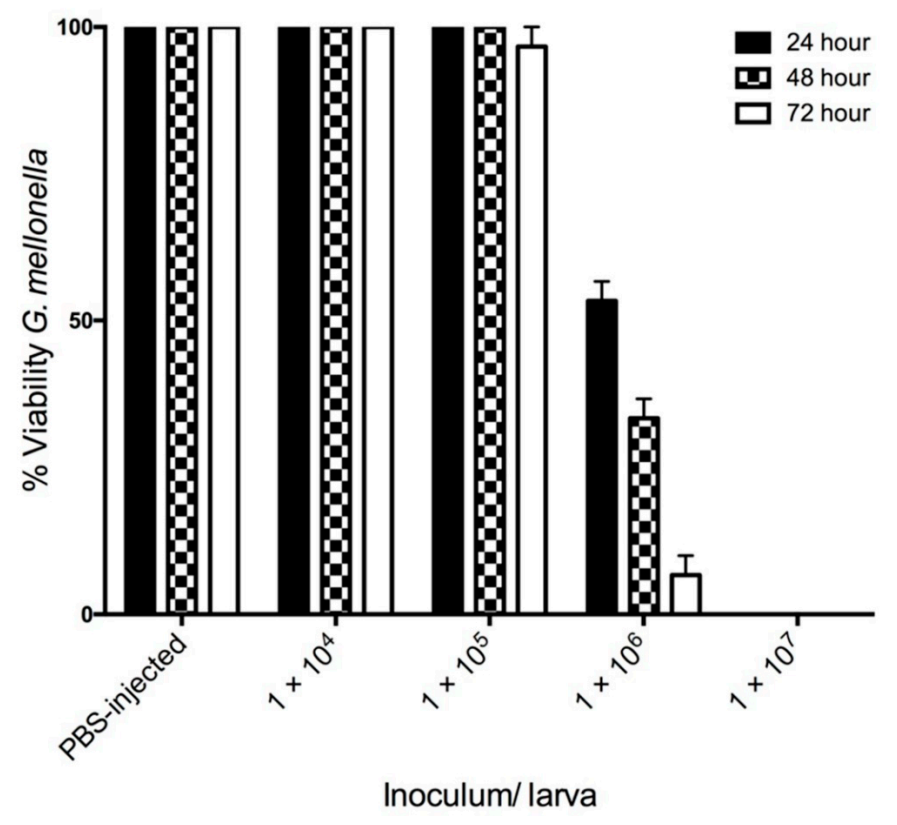

Figure 1. Effect of C. albicans cells on viability of G. mellonella larvae over 72 h. G. mellonella larvae were inoculated with $20 \mu \mathrm{L}$ of $\mathrm{C}$. albicans at doses ranging from $1 \times 10^{4}$ to $1 \times 10^{7}$ incubated at $30^{\circ} \mathrm{C}$ and viability was assessed over $72 \mathrm{~h}$. All values are the mean $\pm \mathrm{SE}$ of three independent experiments.

Cryoviz cryo-imaging was used to visualize the dissemination of C. albicans $\left(5 \times 10^{5} /\right.$ larva) infection from the point of inoculation throughout the larva (Figure 2). Nodules appeared around the perimeter of the hemocoel $6 \mathrm{~h}$ post infection (see black arrows) indicating dissemination of the C. albicans blastospores from the site of infection. By $24 \mathrm{~h}$ there was extensive melanization of larval tissue and cuticle (white arrows) indicating invasion from the insect hemocoel into surrounding tissue, and the formation of large fungal nodules (black arrows) at the site of inoculation and throughout the larva (Figure 2). Visualization of melanized lesions dissected from infected larvae by confocal microscopy at 6 and $24 \mathrm{~h}$ revealed the presence of hyphae (blue arrow) dispersed throughout nodules (Figure 3). At $24 \mathrm{~h}$ hyphae (blue arrow) and yeast cells (orange arrow) are visible. 


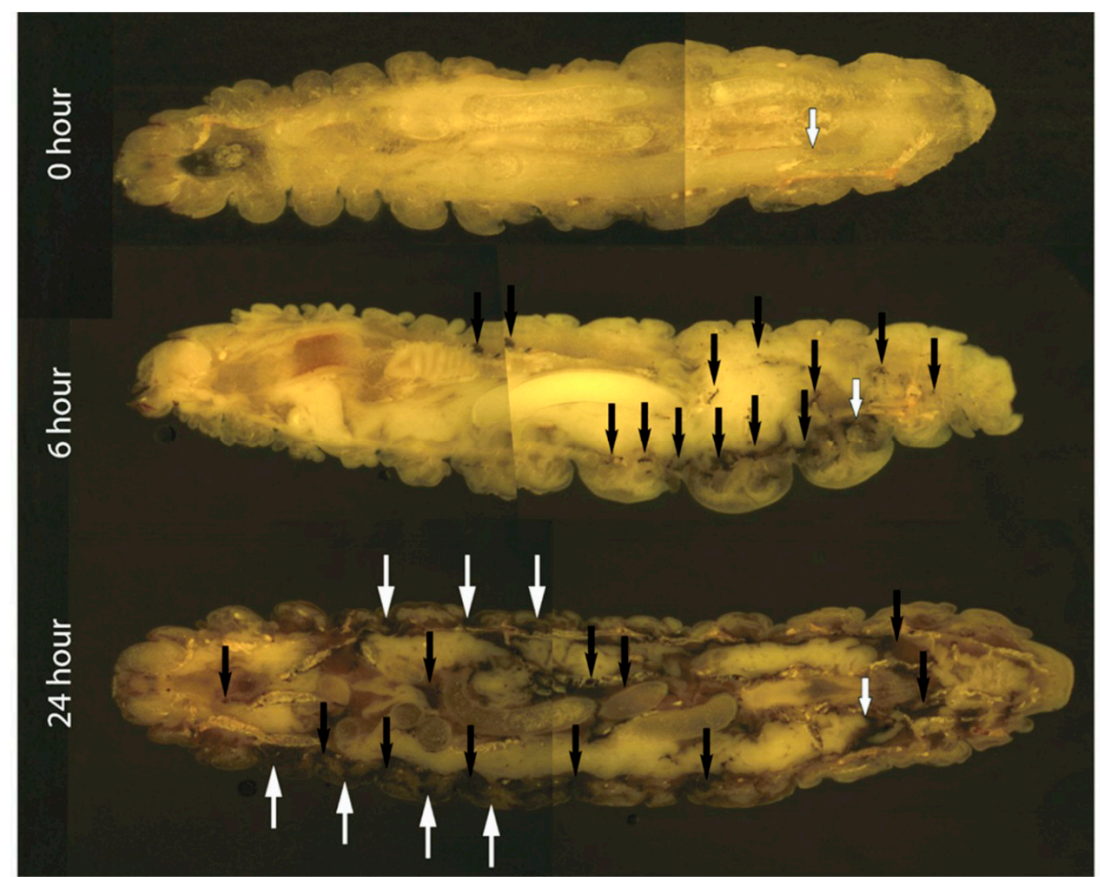

Figure 2. Cryoviz visualization showing the stages of disseminated candidosis in G. mellonella after 6 and $24 \mathrm{~h}$ infection. Larvae were inoculated with $5 \times 10^{5} \mathrm{C}$. albicans cells and incubated for 6 and $24 \mathrm{~h}$. Larvae were embedded in Cryo-imaging embedding compound and sectioned $(10 \mu \mathrm{m})$ using a CryovizTM (Bioinvision Inc., Cleveland, $\mathrm{OH}$ ) cryo-imaging system. (Point of inoculation (white-edged arrow), fungal nodules/granulomas (black arrow), cuticle melanization (white arrows).
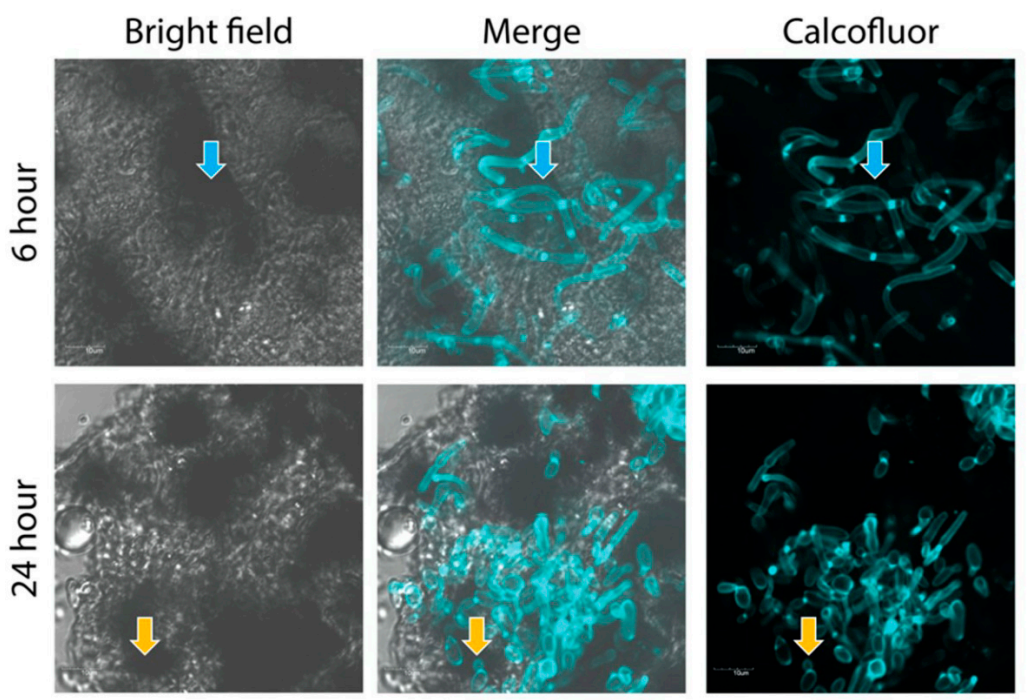

Figure 3. Visualization by confocal microscopy of development of C. albicans yeast and hyphal cells in fungal nodules dissected from infected G. mellonella larvae inoculated with $5 \times 10^{5}$ yeast cells $/ 20 \mu \mathrm{L}$ inoculum. Fungal nodules were dissected from larvae and stained with Calcofluor white. Confocal microscopy revealed the formation of melanized plaques (black clumps within nodules). Fluorescent microscopy of fungal nodules using Calcofluor white fluorescence revealed C. albicans hyphae (blue arrow) at $6 \mathrm{~h}$ post infection. By $24 \mathrm{~h}$ there is the appearance of both hyphal forms and yeast cells (orange arrow) (scale bar corresponds to $10 \mu \mathrm{m}$ ).

\subsection{Characterization of C. albicans Proteins Secreted during Infection of G. mellonella Larvae}

Hemolymph from $C$. albicans infected larvae was isolated $(t=24 \mathrm{~h})$ and MS performed. A total of 101 C. albicans proteins secreted or released during infection were detected in G. mellonella hemolymph. 
Seventeen uncharacterized proteins were detected during infection. Enrichment analysis using FunCat GO terms, identified biological processes such as interaction with host $\left(p=1.4029 \times 10^{-8}\right)$, cellular response to heat $(p=0.040686)$ and pathogenesis $(p=0.032202)$. Molecular functions such as protein binding $\left(p=6.8596 \times 10^{-7}\right)$ and cellular components such as cytoplasm $\left(p=7.7444 \times 10^{-7}\right)$ and hyphal cell wall $\left(p=7.6282 \times 10^{-9}\right)$ were all significantly enriched within this subset of proteins. Proteins associated with the extracellular region $\left(p=6.8596 \times 10^{-7}\right)$ and cell surface $\left(p=1.7438 \times 10^{-12}\right)$ were also enriched indicating these proteins are released or secreted during infection in larval hemolymph, (Table S1).

Proteins that were implicated in pathogenesis were 14-3-3 protein homolog, cell wall protein 1, potential fungal zinc cluster transcription factor, cell wall protein IFF5, cell surface mannoprotein MP65, heat shock protein homolog SSE1, secreted protein RBT4, secreted beta-glucosidase SUN41, and heat shock protein 90 homolog and enolase 1 (Table S2).

\subsection{Assessment of Fungicidal Activity of Larval Hemolymph on Candida albicans (Ex Vivo)}

In order to uncover the fate of $C$. albicans cells when first introduced into the larval hemolymph the fungicidal activity of hemolymph was determined by incubation of yeast cells $\left(10^{6} \mathrm{cells} / \mathrm{mL}\right)$ in different concentrations of hemolymph ex vivo over $24 \mathrm{~h}$. There was a $76 \%$ decrease in the viability of C. albicans after incubation in $100 \%$ hemolymph $\left(0.23 \pm 0.03 \times 10^{6}, p<0.05\right)$ as compared to PBS $\left(0.99 \pm 0.01 \times 10^{6}\right)$ after $0 \mathrm{~h}$ incubation. This effect was also observed after $4\left(0.38 \pm 0.03 \times 10^{6}, p<0.05\right)$ and $6\left(0.25 \pm 0.04 \times 10^{6} p<0.05\right) \mathrm{h}$ incubation as compared to the control. However, incubation of yeast cells in $50 \%$ and $25 \%$ hemolymph after $0 \mathrm{~h}$ resulted in no significant decrease in C. albicans viability. Incubation of $C$. albicans in hemolymph (50\% and 25\%) for 2, 4 and $6 \mathrm{~h}$ resulted in a decrease in yeast viability. After $24 \mathrm{~h}$, the growth of $C$. albicans in whole hemolymph remained below the control, however diluted hemolymph $\left(50 \%\left(1.35 \pm 0.23 \times 10^{6}\right)\right.$ and $\left.25 \%\left(1.91 \pm 0.08 \times 10^{6}\right)\right)$ stimulated the growth of C. albicans, (Figure 4).

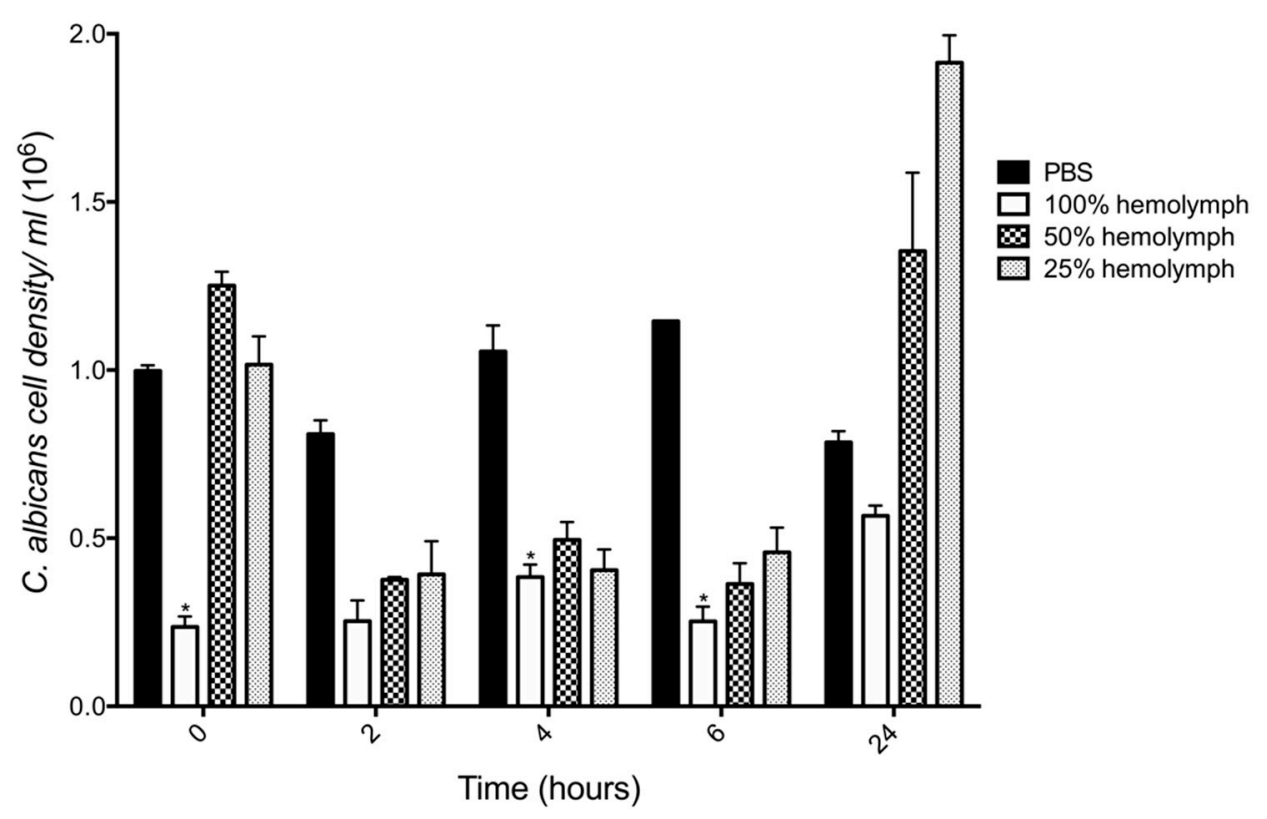

Figure 4. Candidacidal activity of G. mellonella larval hemolymph. C. albicans was incubated $\left(30{ }^{\circ} \mathrm{C}\right)$ in varying concentrations $(100 \%, 50 \%, 25 \%)$ of ex vivo hemocyte-free hemolymph or PBS and dilutions were plated on YEPD agar plates to assess viability. Incubation of C. albicans in $100 \%$ hemolymph decreased yeast cell viability by $76 \%$ at $t=0$ incubation, by $64 \%$ at $t=4 \mathrm{~h}$ and $78 \%$ at $t=6 \mathrm{~h}$. All values are the mean \pm S.E of three independent experiments, $\left({ }^{*}: p<0.05\right)$. 


\subsection{Proteomic Response of C. albicans to G. mellonella Hemolymph (Ex Vivo)}

In order to understand how $C$. albicans responds to and survives the significant fungicidal activity of hemolymph and ultimately disseminates throughout the host, label free quantitative proteomic analysis was conducted on the proteome of C. albicans exposed to G. mellonella hemolymph (100\%) and PBS (control) for $6 \mathrm{~h}$ at $30^{\circ} \mathrm{C}$, (Figure 5). In total, 19,696 peptides were identified representing 1231 proteins with two or more peptides and 786 (hemolymph treated versus PBS treated C. albicans) proteins were determined to be statistically significant differentially abundant (SSDA; ANOVA, $p<0.05$ ) with a fold change of $>1.5$ (260 increased and 526 decreased). A total of 361 proteins were deemed exclusive (i.e., with LFQ intensities present in all three replicates of one treatment and absent in all three replicates of the other treatment). These proteins were also used in statistical analysis of the total differentially expressed group following imputation of the zero values as described. After data imputation these proteins were included in subsequent statistical analysis. A principal component analysis (PCA) performed on all filtered proteins distinguished the hemolymph and PBS treated C. albicans samples indicating a clear difference between each proteome (Figure S1).

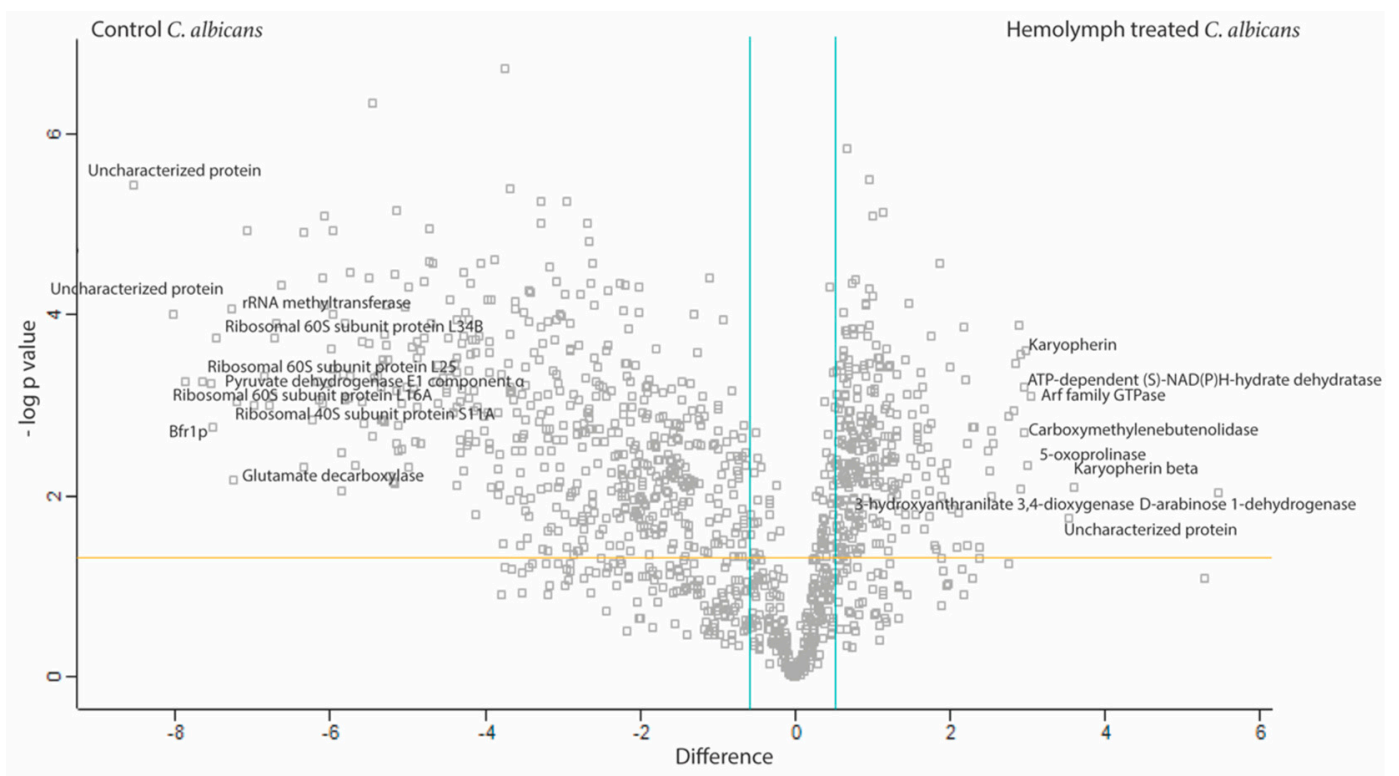

Figure 5. Shotgun proteomics of responses of C. albicans $\left(2.5 \times 10^{7} / \mathrm{mL}\right)$ to G. mellonella hemolymph $(100 \%)$ after $6 \mathrm{~h}$ incubated at $30^{\circ} \mathrm{C}$. Volcano plots showing the distribution of quantified proteins according to $p$ value ( $-\log 10 p$-value) and fold change (log2 mean LFQ intensity difference). Proteins above the horizontal line are considered statistically significant $(p$ value $<0.05)$ and those to the right and left of the vertical lines indicate relative fold changes \pm 1.5 . C. albicans responds to hemolymph by altering the abundance of a range of proteins associated with a variety of biological process (enrichment for; translation, glycolytic process, protein folding, oxidation-reduction process, and interaction with host), molecular functions (structural constituent of ribosome, RNA binding, and metallopeptidase activity) and cellular components (cytoplasm, ribosome and cell surface).

FungiFun analysis revealed enrichment for biological processes such as translation $\left(p=6.6882 \times 10^{-35}\right)$, glycolytic process $\left(p=1.8762 \times 10^{-7}\right)$, protein folding $\left(p=1.1493 \times 10^{-6}\right)$, oxidation-reduction process $\left(p=9.7092 \times 10^{-6}\right)$ and interaction with host $(p=0.00022661)$ in the C. albicans incubated in hemolymph. Molecular functions such as structural constituent of ribosome $\left(p=3.2372 \times 10^{-19}\right)$, RNA binding $(p=0.000003489)$ and metallopeptidase activity $(p=0.013756)$. Cellular components of the cytoplasm $\left(p=2.7786 \times 10^{-36}\right)$, ribosome $\left(p=1.7021 \times 10^{-19}\right)$, and cell surface $\left(p=1.5316 \times 10^{-9}\right)$ were also enriched within the SSDA proteins from C. albicans incubated in hemolymph ex vivo (Table S3). These results were confirmed by STRING analysis (Figure 6). 

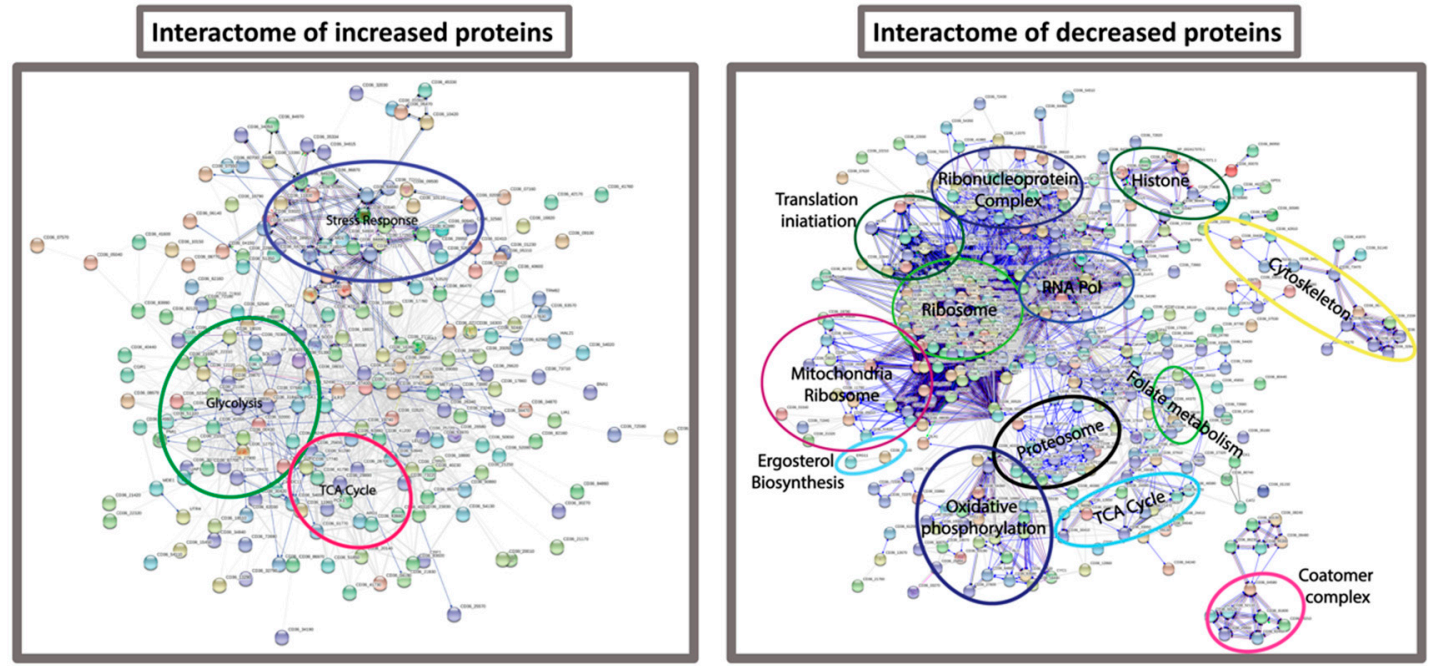

Figure 6. Interactome of proteins increased and decreased in abundance in C. albicans incubated in G. mellonella hemolymph. Protein interaction information was obtained from the STRING database using gene lists extracted for statistically significant differentially abundant (SSDA) proteins from pair wise $t$-tests $(p<0.05)$. Each node represents a protein and each connecting line represents an interaction, the extent of evidence for which is represented by the width of the line. Statistically enriched biological process Gene Ontology descriptors were examined to identify clusters of proteins enriched within SSDA protein lists.

The top 10 proteins increased in abundance in C. albicans incubated in hemolymph were D-arabinose 1-dehydrogenase (44 fold), karyopherin beta (12 fold), uncharacterized protein (11.5 fold), Arf family GTPase ( 8 fold), 5-oxoprolinase ( 8 fold), karyopherin ( 8 fold), carboxymethylenebutenolidase ( 8 fold), ATP-dependent (S)-NAD(P)H-hydrate dehydratase (8 fold), 3-hydroxyanthranilate 3,4-dioxygenase ( 8 fold) and Leu42p ( 7.5 fold), (Table S4A). The top 10 proteins decreased in abundance in C. albicans incubated in hemolymph were uncharacterized protein ( 374 fold), uncharacterized protein (259.5 fold), ribosomal 60S subunit protein L16A ( 235 fold), ribosomal 60S subunit protein L25 (201.5 fold), pyruvate dehydrogenase E1 component subunit alpha (187 fold), Bfr1p (184 fold), ribosomal 60S subunit protein L34B (176 fold), rRNA methyltransferase (155.5 fold), glutamate decarboxylase (152 fold) and ribosomal 40 S subunit protein S11A (149 fold), (Table S4B).

\section{Discussion}

C. albicans is the most common nosocomial fungal pathogen of humans and causes a broad spectrum of diseases depending on the immune status of the host with a mortality rate of $40 \%$ in certain patient groups [22]. C. albicans possesses an arsenal of virulence factors to establish a focal point of infection, adhere to and invade host cells, detoxify the cellular immune response and degrade components of the humoral immune response [27]. The C. albicans cell wall is also a complex mesh of polysaccharides, proteins and sterols which help to form a physical barrier against the immune response but also signals are relayed from the wall depending on the stimulus in order for the fungal cell to adequately mount an appropriate stress response [28].

In this study, the infection processes and responses of C. albicans following exposure to G. mellonella hemolymph were investigated. Infection with $C$. albicans resulted in a dose dependent decrease in larval viability over $72 \mathrm{~h}$. An inoculum of $1 \times 10^{5}$ resulted in no change in viability, while $1 \times 10^{6}$ yeast cells reduces larval viability to $6.66 \pm 3.33 \%$ after $72 \mathrm{~h}$, (Figure 1). The use of Cryo-imaging revealed infection by $C$. albicans commenced immediately with extensive melanization around the area of inoculation at $6 \mathrm{~h}$ (Figure 2). There were discrete nodules in the middle of the larvae and these consisted of viable fungal hyphae. By $24 \mathrm{~h}$ larvae were heavily infected with disseminated C. albicans as observed by extensive cuticular melanization and the appearance of large nodules throughout the host. A similar process has 
been documented in patients with chronic candidiasis where immune cells surround the pathogen and initiate an inflammatory response to prevent dissemination [29]. Dissection of nodules at 6 and $24 \mathrm{~h}$ revealed the presence of hyphae at 6 hour with the addition of yeast cells at $24 \mathrm{~h}$ (Figure 3).

Proteins released by C. albicans during infection of larvae were also analyzed. In total 101 C. albicans proteins were found in hemolymph during infection and biological processes such as interaction with host $\left(p=1.4029 \times 10^{-8}\right)$, cellular response to heat $(p=0.040686)$ and pathogenesis $(p=0.032202)$ were enriched. Interestingly, cell wall protein 1 is a heme-binding protein involved in heme-iron utilization and required for biofilm formation and is preferentially expressed during the mycelium growth phase, induced by iron starvation and ciclopirox [30-32]. Peroxiredoxin is a thiol specific peroxidase that catalyses the reduction of hydrogen peroxide and also plays a role in cell wall protection against oxidative stress [33]. Enolase 1 binds to plasminogen and results in enhanced invasion of human brain microvascular endothelial cells [34]. Heat shock protein SSA1 binds to histatin 5 , an important antimicrobial peptide against $C$. albicans oral infection [35]. Cell surface mannoprotein MP65 which is a major antigen and induces T-cell proliferation, DC maturation and is required for hyphal morphogenesis and surface adherence during infection [36,37]. Antigenic secreted protein RBT4 acts as a virulence factor during infections and plays a role in protection against phagocyte attack [38]. Moreover, a range of cell wall derived proteins were detected in hemolymph such as chitin synthase, cell wall protein PGA59, cell wall protein IFF5 and secreted beta-glucosidase SUN41. Proteins associated with translation (translation initiation factor eIF2B subunit delta, translation factor GUF1, translation elongation factor 1 subunit beta) and the ribosome (60S ribosomal protein L27) were detected in hemolymph and may have been released from C. albicans during cell death.

Exposure of yeast cells to larval hemolymph resulted in significant reductions in viability. At $t=0$, $100 \%$ hemolymph reduced the viability of $C$. albicans by $76 \%\left(0.23 \pm 0.03 \times 10^{6}, p<0.05\right)$ as compared to the PBS control $\left(0.99 \pm 0.01 \times 10^{6}\right)$, (Figure 4). This indicates that the candicidal activity of hemolymph is highly active even in naïve larvae. C. albicans viability remained significantly lower than that of the control at 4 and $6 \mathrm{~h}$. G. mellonella hemolymph is rich in antimicrobial peptides and proteins such as cecropins, moricins, gloverins, 6-tox, lysozyme, gallerimycin, and galliomicin. Many of these peptides have fungicidal activity and C. albicans increases the abundance of cecropins during infection [18]. Furthermore, cecropin-A induced apoptosis of C. albicans by disrupting intracellular ion balance and the glutathione antioxidant system [19]. A range of these AMPs are inducible thus indicating that naive hemolymph has significant constitutively expressed antifungal molecules. Cecropins and moricins are increased in abundance at $6 \mathrm{~h}$ post infection with C. albicans and A. fumigatus respectively in G. mellonella larvae $[10,18]$.

In order to characterize the molecular responses of C. albicans to hemolymph, protein was extracted from the cells after $6 \mathrm{~h}$ exposure to hemolymph ex vivo and subjected to mass spectrometry. STRING analysis of proteins decreased in abundance from C. albicans cells incubated in hemolymph revealed enrichment for biological processes associated with the ribosome, translation, and ribonucleoprotein complex. A decrease in these proteins indicates a decrease in global protein synthesis. Gene expression associated with protein synthesis was decreased late during experimental bloodstream infection in mice and this decrease in protein synthesis was associated with an increase in gene expression associated with glycolysis, oxidative stress, fermentation, and genes associated with interaction with the host which it may use to escape from the bloodstream [39]. Larval hemolymph induced increases in the abundance of $C$. albicans proteins associated with the same processes. Incubation of $C$. albicans in human serum and G. mellonella hemolymph activates similar processes in order for the fungal cell to survive in the host. Furthermore, proteins associated with oxidative phosphorylation, the TCA cycle and the mitochondria were all decreased in abundance probably resulting in an overall decrease in cellular respiration [40]. C. albicans deficient in respiration were resistant to histatin 5 and disruption of mitochondria also allows increased growth in the presence of amphotericin B [41]. Therefore a decrease in mitochondrial respiration may allow the cell to withstand the hostile environment within hemolymph during infection. 
Proteins associated with an oxidative stress response such as thioredoxin, thioredoxin reductase, superoxide dismutase, glutathione-disulfide reductase, thioredoxin peroxidase were increased in abundance in hemolymph-incubated cells. Heat shock proteins (hsp) such as hsp homolog SSE1, hsp SSA1, hsp SSA2 and hsp SSC1 were also elevated in abundance. Hsp SSA1 and SSA2 induce host cell endocytosis which lead to increased virulence [42] and also play a role in resistance to antimicrobial peptides and antifungal agents $[35,43,44]$. Interestingly, hsp SSA1 and peroxiredoxin TSA1 were also found secreted into G. mellonella hemolymph during infection in this study. Candidapepsin-9 is a glycosylphosphatidylinositol-anchored protease and important virulence factor found to activate human neutrophils more effectively than any other SAP [45] and was increased 1.8 fold in C. albicans incubated in hemolymph in this study.

\section{Conclusions}

Upon infection, C. albicans disseminates through G. mellonella larvae in a similar way to mammals. Exposure of $C$. albicans to hemolymph leads to the activation of processes associated with a decrease in protein synthesis and an increase in the abundance of proteins associated with pathogenesis, glycolysis, and responses to oxidative stress. Some of these proteins are secreted and detectable in hemolymph during infection. The results presented here indicate that upon infection of G. mellonella larvae with C. albicans there is the activation of similar processes in C. albicans by insect hemolymph as are activated by human sera and uncovering these similarities will further extend the utility of this system for studying pathogen-host interactions.

Supplementary Materials: The following are available online at http://www.mdpi.com/2309-608X/5/1/7/s1; Figure S1: Shotgun quantitative proteomic analysis of C. albicans incubated in G. mellonella 100\% hemolymph for $6 \mathrm{~h}$ at $30^{\circ} \mathrm{C}$, Table S1: Functional enrichment of C. albicans proteins released during infection of G. mellonella larvae. Table S2: List of proteins detected in G. mellonella larval hemolymph after $24 \mathrm{~h}$ infection with C. albicans at $30^{\circ} \mathrm{C}$. Table S3: Functional enrichment of proteins differentially abundant proteins from C. albicans exposed to G. mellonella larvae hemolymph. Table S4: List of proteins detected which were statistically significant and differentially (A; Increased, B; Decreased) in C. albicans incubated in G. mellonella hemolymph as compared to PBS after $6 \mathrm{~h}$ incubated at $30^{\circ} \mathrm{C}$.

Author Contributions: G.S. and K.K. designed the experiments. G.S. performed the experiments and analyzed the results. G.S. and K.K. wrote the manuscript. G.S. and K.K. have read and approved the manuscript.

Funding: Gerard Sheehan is the recipient of a Maynooth University Doctoral studentship. Q-exactive mass spectrometer was funded under the SFI Research Infrastructure Call 2012; Grant Number: 12/RI/2346 (3).

Acknowledgments: The assistance of Ilona Dix with Cryoviz imaging and Confocal microscopy is acknowledged.

Conflicts of Interest: The authors declare no conflict of interest.

\section{References}

1. Cotter, G.; Doyle, S.; Kavanagh, K. Development of an insect model for the in vivo pathogenicity testing of yeasts. FEMS Immunol. Med. Microbiol. 2000, 27, 163-169. [CrossRef] [PubMed]

2. Brennan, M.; Thomas, D.Y.; Whiteway, M.; Kavanagh, K. Correlation between virulence of Candida albicans mutants in mice and Galleria mellonella larvae. FEMS Immunol. Med. Microbiol. 2002, 34, 153-157. [CrossRef] [PubMed]

3. Slater, J.L.; Gregson, L.; Denning, D.W.; Warn, P.A. Pathogenicity of Aspergillus fumigatus mutants assessed in Galleria mellonella matches that in mice. Med. Mycol. 2011, 49, S107-S113. [CrossRef] [PubMed]

4. Reeves, E.P.; Messina, C.G.M.; Doyle, S.; Kavanagh, K. Correlation between gliotoxin production and virulence of Aspergillus fumigatus in Galleria mellonella. Mycopathologia 2004, 158, 73-79. [CrossRef] [PubMed]

5. O'Hanlon, K.A.; Cairns, T.; Stack, D.; Schrettl, M.; Bignell, E.M.; Kavanagh, K.; Miggin, S.M.; O’Keeffe, G.; Larsen, T.O.; Doyle, S. Targeted disruption of nonribosomal peptide synthetase Pes3 augments the virulence of Aspergillus fumigatus. Infect. Immun. 2011, 79, 3978-3992. [CrossRef] [PubMed]

6. Jander, G.; Rahme, L.G.; Ausubel, F.M. Positive correlation between virulence of Pseudomonas aeruginosa mutants in mice and insects. J. Bacteriol. 2000, 182, 3843-3845. [CrossRef] [PubMed] 
7. Senior, N.J.; Bagnall, M.C.; Champion, O.L.; Reynolds, S.E.; la Ragione, R.M.; Woodward, M.J.; Salguero, F.J.; Titball, R.W. Galleria mellonella as an infection model for campylobacter jejuni virulence. J. Med. Microbiol. 2011, 60, 661-669. [CrossRef]

8. Kavanagh, K.; Reeves, E.P. Exploiting the potential of insects for in vivo pathogenicity testing of microbial pathogens. FEMS Microbiol. Rev. 2004, 28, 101-112. [CrossRef]

9. Kavanagh, K.; Sheehan, G. The Use of Galleria mellonella Larvae to Identify Novel Antimicrobial Agents against Fungal Species of Medical Interest. J. Fungi 2018, 4, 113. [CrossRef]

10. Sheehan, G.; Clarke, G.; Kavanagh, K. Characterisation of the cellular and proteomic response of Galleria mellonella larvae to the development of invasive aspergillosis. BMC Microbiol. 2018, 18. [CrossRef]

11. Fuchs, B.B.; O’Brien, E.; El Khoury, J.B.; Mylonakis, E. Methods for using Galleria mellonella as a model host to study fungal pathogenesis. Virulence 2010, 1, 475-482. [CrossRef] [PubMed]

12. Sheehan, G.; Garvey, A.; Croke, M.; Kavanagh, K. Innate humoral immune defences in mammals and insects: The same, with differences? Virulence 2018, 9, 1625-1639. [CrossRef] [PubMed]

13. Schuhmann, B.; Seitz, V.; Vilcinskas, A.; Podsiadlowski, L. Cloning and expression of gallerimycin, an antifungal peptide expressed in immune response of greater wax moth larvae, Galleria mellonella. Arch. Insect Biochem. Physiol. 2003, 53, 125-133. [CrossRef] [PubMed]

14. Lee, Y.S.; Yun, E.K.; Jang, W.S.; Kim, I.; Lee, J.H.; Park, S.Y.; Ryu, K.S.; Seo, S.J.; Kim, C.H.; Lee, I.H. Purification, cDNA cloning and expression of an insect defensin from the great wax moth, Galleria mellonella. Insect Mol. Biol. 2004, 13, 65-72. [CrossRef] [PubMed]

15. Seitz, V.; Clermont, A.; Wedde, M.; Hummel, M.; Vilcinskas, A.; Schlatterer, K.; Podsiadlowski, L. Identification of immunorelevant genes from greater wax moth (Galleria mellonella) by a subtractive hybridization approach. Dev. Comp. Immunol. 2003, 27, 207-215. [CrossRef]

16. Bolouri Moghaddam, M.R.; Tonk, M.; Schreiber, C.; Salzig, D.; Czermak, P.; Vilcinskas, A.; Rahnamaeian, M. The potential of the Galleria mellonella innate immune system is maximized by the co-presentation of diverse antimicrobial peptides. Biol. Chem. 2016, 397, 939-945. [CrossRef] [PubMed]

17. Brown, S.E.; Howard, A.; Kasprzak, A.B.; Gordon, K.H.; East, P.D. The discovery and analysis of a diverged family of novel antifungal moricin-like peptides in the wax moth Galleria mellonella. Insect Biochem. Mol. Biol. 2008, 38, 201-212. [CrossRef] [PubMed]

18. Sheehan, G.; Kavanagh, K. Analysis of the early cellular and humoral responses of Galleria mellonella larvae to infection by Candida albicans. Virulence 2018, 9, 163-172. [CrossRef] [PubMed]

19. Yun, J.E.; Lee, D.G. Cecropin A-induced apoptosis is regulated by ion balance and glutathione antioxidant system in Candida albicans. IUBMB Life 2016, 652-662. [CrossRef]

20. Lee, E.; Shin, A.; Kim, Y. Anti-inflammatory activities of cecropin A and its mechanism of action. Arch. Insect Biochem. Physiol. 2015, 88, 31-44. [CrossRef]

21. Moazeni, M.; Asgari, S.; Nabili, M. Nosocomial fungal infections: Epidemiology, diagnosis, treatment and prevention. J. Maz. Univ. Med. Sci. 2018, 28, 182-212.

22. Brown, G.D.; Denning, D.W.; Gow, N.A.R.; Levitz, S.M.; Netea, M.G.; White, T.C. Hidden Killers: Human Fungal Infections. Sci. Transl. Med. 2012, 4, 1-9. [CrossRef] [PubMed]

23. Mayer, F.L.; Wilson, D.; Hube, B. Candida albicans pathogenicity mechanisms. Virulence 2013, 4, 119-128. [CrossRef] [PubMed]

24. Priebe, S.; Linde, J.; Albrecht, D.; Guthke, R.; Brakhage, A.A. FungiFun: A web-based application for functional categorization of fungal genes and proteins. Fungal Genet. Biol. 2011, 48, 353-358. [CrossRef] [PubMed]

25. Jensen, L.J.; Kuhn, M.; Stark, M.; Chaffron, S.; Creevey, C.; Muller, J.; Doerks, T.; Julien, P.; Roth, A.; Simonovic, M.; et al. STRING 8-A global view on proteins and their functional interactions in 630 organisms. Nucleic Acids Res. 2009, 37. [CrossRef] [PubMed]

26. Côté, R.G.; Griss, J.; Dianes, J.A.; Wang, R.; Wright, J.C.; van den Toorn, H.W.P.; van Breukelen, B.; Heck, A.J.R.; Hulstaert, N.; Martens, L.; et al. The PRoteomics IDEntification (PRIDE) Converter 2 Framework: An Improved Suite of Tools to Facilitate Data Submission to the PRIDE Database and the ProteomeXchange Consortium. Mol. Cell. Proteom. 2012, 11, 1682-1689. [CrossRef] [PubMed]

27. Calderone, R.A.; Fonzi, W.A. Virulence factors of Candida albicans. Trends Microbiol. 2001, 9, 327-335. [CrossRef] 
28. Ruiz-Herrera, J.; Victoria Elorza, M.; Valentín, E.; Sentandreu, R. Molecular organization of the cell wall of Candida albicans and its relation to pathogenicity. FEMS Yeast Res. 2006, 6, 14-29. [CrossRef]

29. Misme-Aucouturier, B.; Albassier, M.; Alvarez-Rueda, N.; Pape, P. Le Specific human and Candida cellular interactions lead to controlled or persistent infection outcomes during granuloma-like formation. Infect. Immun. 2017, 85, e00807-16. [CrossRef]

30. Weissman, Z.; Kornitzer, D. A family of Candida cell surface haem-binding proteins involved in haemin and haemoglobin-iron utilization. Mol. Microbiol. 2004, 53, 1209-1220. [CrossRef]

31. Sigel, H.C.; Thewes, S.; Niewerth, M.; Korting, H.C.; Schäder-Korting, M.; Hube, B. Oxygen accessibility and iron levels are critical factors for the antifungal action of ciclopirox against Candida albicans. J. Antimicrob. Chemother. 2005, 55, 663-673. [CrossRef] [PubMed]

32. Pérez, A.; Pedrós, B.; Murgui, A.; Casanova, M.; López-Ribot, J.L.; Martínez, J.P. Biofilm formation by Candida albicans mutants for genes coding fungal proteins exhibiting the eight-cysteine-containing CFEM domain. FEMS Yeast Res. 2006, 6, 1074-1084. [CrossRef]

33. Urban, C.; Xiong, X.; Sohn, K.; Schröppel, K.; Brunner, H.; Rupp, S. The moonlighting protein Tsa1p is implicated in oxidative stress response and in cell wall biogenesis in Candida albicans. Mol. Microbiol. 2005, 57, 1318-1341. [CrossRef]

34. Jong, A.Y.; Chen, S.H.M.; Stins, M.F.; Kim, K.S.; Tuan, T.L.; Huang, S.H. Binding of Candida albicans enolase to plasmin(ogen) results in enhanced invasion of human brain microvascular endothelial cells. J. Med. Microbiol. 2003, 52, 615-622. [CrossRef] [PubMed]

35. Li, X.S.; Reddy, M.S.; Baev, D.; Edgerton, M. Candida albicans Ssa1/2p is the cell envelope binding protein for human salivary histatin 5. J. Biol. Chem. 2003, 278, 28553-28561. [CrossRef] [PubMed]

36. Pietrella, D.; Bistoni, G.; Corbucci, C.; Perito, S.; Vecchiarelli, A. Candida albicans mannoprotein influences the biological function of dendritic cells. Cell. Microbiol. 2006, 8, 602-612. [CrossRef] [PubMed]

37. Sandini, S.; Stringaro, A.; Arancia, S.; Colone, M.; Mondello, F.; Murtas, S.; Girolamo, A.; Mastrangelo, N.; De Bernardis, F. The MP65 gene is required for cell wall integrity, adherence to epithelial cells and biofilm formation in Candida albicans. BMC Microbiol. 2011, 11. [CrossRef] [PubMed]

38. Braun, B.R.; Head, W.S.; Wang, M.X.; Johnson, A.D. Identification and characterization of TUP1-regulated genes in Candida albicans. Genetics 2000, 156, 31-44. [CrossRef] [PubMed]

39. Fradin, C.; Kretschmar, M.; Nichterlein, T.; Gaillardin, C.; D’Enfert, C.; Hube, B. Stage-specific gene expression of Candida albicans in human blood. Mol. Microbiol. 2003, 47, 1523-1543. [CrossRef]

40. Gyurko, C.; Lendenmann, U.; Troxler, R.F.; Oppenheim, F.G. Candida albicans mutants deficient in respiration are resistant to the small cationic salivary antimicrobial peptide histatin 5. Antimicrob. Agents Chemother. 2000. [CrossRef]

41. Geraghty, P.; Kavanagh, K. Disruption of mitochondrial function in Candida albicans leads to reduced cellular ergosterol levels and elevated growth in the presence of amphotericin B. Arch. Microbiol. 2003. [CrossRef] [PubMed]

42. Sun, J.N.; Solis, N.V.; Phan, Q.T.; Bajwa, J.S.; Kashleva, H.; Thompson, A.; Liu, Y.; Dongari-Bagtzoglou, A.; Edgerton, M.; Filler, S.G. Host cell invasion and virulence mediated by Candida albicans Ssa1. PLoS Pathog. 2010, 6. [CrossRef] [PubMed]

43. Cho, T.; Toyoda, M.; Sudoh, M.; Nakashima, Y.; Calderone, R.A.; Kaminishi, H. Isolation and sequencing of the Candida albicans MS13, a putative novel member of the HSP70 family. Yeast 2003, 20, 149-156. [CrossRef] [PubMed]

44. Nagao, J.I.; Cho, T.; Uno, J.; Ueno, K.; Imayoshi, R.; Nakayama, H.; Chibana, H.; Kaminishi, H. Candida albicans Msi3p, a homolog of the Saccharomyces cerevisiae Sse1p of the Hsp70 family, is involved in cell growth and fluconazole tolerance. FEMS Yeast Res. 2012, 12, 728-737. [CrossRef] [PubMed]

45. Hornbach, A.; Heyken, A.; Schild, L.; Hube, B.; Löffler, J.; Kurzai, O. The glycosylphosphatidylinositol-anchored protease Sap9 modulates the interaction of Candida albicans with human neutrophils. Infect. Immun. 2009, 77, 5216-5224. [CrossRef] [PubMed]

(C) 2019 by the authors. Licensee MDPI, Basel, Switzerland. This article is an open access article distributed under the terms and conditions of the Creative Commons Attribution (CC BY) license (http:/ / creativecommons.org/licenses/by/4.0/). 